\author{
Ощепков О.П. \\ кандидат економічних наук, доцент \\ кафедра обліку та аудиту \\ E-mail: moto47rod@gmail.com \\ ORCID ID: 0000-0002-7520-1507 \\ Магденко C.O. \\ старший викладач \\ кафедра економіки промисловості \\ Одеська національна академія харчових технологій \\ вул. Канатна, 112, м. Одеса, Україна, 65039 \\ E-mail: maglana1@meta.ua \\ ORCID ID: 0000-0001-6770-6604
}

\title{
АНАЛІЗ ВЛАСНОГО КАПІТАЛУ М'ЯСОПЕРЕРОБНИХ ПІДПРИЄМСТВ УКРАЇНИ ЯК ОСНОВНОГО ДЖЕРЕЛА ЇХНЬОГО ФІНАНСУВАННЯ ТА РОЗВИТКУ
}

В статті розглядаються питання фрормування, розподілу та використання власного капіталу як основного джерела фрінансування та розвитку підприємства. Задача полягає в ефективності розподілу власного капіталу між окремими елементами, тобто між основним і оборотним капіталом, матеріальними і нематеріальними активами з метою досягнення максимального ефекту від його використання.

Розглянуті різні підходи до поняття «власний капітал», а також визначені його функції, які повинні забезпечити стабільність функціонування і розвитку підприємства, зменшити економічні ризики в умовах нестабільності розвитку країни. Проведено аналіз формування, розподілу та використання власного капіталу на підприємствах м'ясопереробної галузі України, розраховано ефективність використання власного капіталу. М'ясопереробні підприємства вибрані з урахуванням різної суми загальної суми активів та власного капіталу. Результати дослідження дозволяють зробити висновки, що на більшості підприємств відсутні додаткові фронди, як елементи власного капіталу при значній збитковості діяльності підприємств, що значно зменшує частку власного капіталу в структурі всього капіталу і збільшує частину позикового капіталу, через що підприємства стають неконкурентоспроможними на ринку. Недостатність власних ресурсів та висока вартість зовнішніх коштів не дозволяє підприємствам впроваджувати новітні техніку та технології, переходити на інноваційні фоорми розвитку. Також відсутність державної підтримки, високі податкові навантаження спонукають використовувати схеми подвійної бухгалтерії, тіньового ринку.

Ключові слова: капітал, власний капітал, аналіз, структура, оптимальність (ефективність).

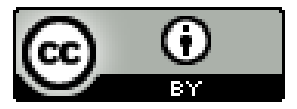

This work is licensed under a Creative Commons Attribution 4.0 International License http://creativecommons.org/licenses/by/4.0/
Постановка проблеми та її зв'язок з важливими науковими та практичними завданнями. Початок будь-якої господарської діяльності здійснюється 3 формування власного капіталу у вигляді зареєстровано або пайового капіталу, розмір якого вказаний в статуті підприємства відповідно організаційноправової форми та нормативно-законодавчих актів.

Для ефективного управління діяльністю підприємства важливо своєчасно отримати інформацію про структуру сформованого власного капіталу, яка його частина розміщена в основні засоби, нематеріальні активи, матеріальні ресурси та грошові кошти. Таким чином процес управління власним капіталом, включаючи механізм його формування та механізм розміщення необоротних та оборотних активів $є$ актуальною для дослідження.
Аналіз останніх публікацій по проблемі. Дослідження формування структури капіталу присвячено багато робіт як іноземних, так і вітчизняних вчених, таких як Ю.Брігхама, Г. Марковіца, Е. Хенферба, Г. Савицької, Є. Панченка, О. Рогач, О.Яріш та інш., які більш уваги приділяли співвідношенню власного та позикового капіталу, оптимізації його структури. Питання поняття власного капіталу, аналізу його структури, динаміки та методики обліку розглядаються такими науковцями як Ф.Ф. Бутинець, I.О. Бланк, О.Вівчар, А. Хмелевська, В.П. Сопко, О.Д.Щербань та ін. Разом з тим, теоретичні та методичні питання щодо власного капіталу підприємства $€$ актуальними й до теперішнього часу.

Питання управління власним капіталом підприємством, інформаційно-аналітичне забезпечення прийняття управлінських рішень 3 формування та 
використання власного капіталу розглядаються в роботах науковців: К. Багрія, І.Данилюка, О. Мельника, С. Рутківської та ін.

Разом $з$ тим, на нашу думку, питання оптимізації структури як власного, так і загального капіталу підприємства, ефективності використання його елементів та їх вплив на рівень його рентабельності серед вчених залишаються дискусійними.

Формування цілей дослідження. Розкрити фактори впливу на формування, розподіл та використання власного капіталу підприємства як основного джерела його фінансування та розвитку.

Виклад основних результатів та їх обгрунтування. Сутність капіталу як економічної категорії досліджується науковцями тривалий час. Розглядаючи капітал як самозростаючу вартість, К. Маркс поділяв його, в залежності від функцій його відтворення, на постійний та змінний капітал, а розподіл капіталу на основний та оборотний грунтується на розміщенні капітальної вартості, функціонуючої в процесі виробництва [1, с. 183-187]. Особливе значення при прийнятті управлінських рішень має інформація про власний капітал як основного джерела становлення, розвитку та функціонування підприємства. Власний капітал підприємства являє собою основне джерело отримання доходів його власників та прибутку. Його розмір та динаміка змін характеризують рівень ефективності ведення господарської діяльності.

Морфологічну оцінку поняття «власний капітал» підприємства різних авторів розглядають О.Д. Щербань та М.О. Струкова [2, С.737-738], підходи яких щодо розкриття сутності власного капіталу можна поділити на три групи. Перша група авторів характеризує власний капітал загальна вартість засобів підприємства (О.А.Нужна, Ф.Ф. Бутинець). Друга група авторів трактує власний капітал як сума власних коштів підприємства (В.В.Собко, А.А.Горбатенко), Третя група розглядає власний капітал як фінансові ресурси підприємства (О.Й. Вівчар, Л.І.Катан, О.Д.Щербань). Усі ці підходи мають місто існувати. Об'єднуючі всі підходи до сутності поняття «власний капітал», можна вважати, що власний капітал - це є основне джерело формування фінансових ресурсів підприємства, які можуть приймати різну форму його розміщення: матеріальну, нематеріальну, грошову для реалізації мети його діяльності.

Різноманітність форм власного капіталу, його структура и абсолютна величина повинні забезпечити виконання ряд функцій, які спрямовані на забезпечення стабільності функціонування і розвитку підприємства, інвестиційну привабливість, високій рівень капіталізації і конкурентоспроможність на ринку товарів і послуг. Виконання таких функцій значно знизить економічні ризики діяльності підприємства.

Також при формуванні структури власного капіталу необхідно враховувати його розподіл на матеріальну та нематеріальну частину і специфіку діяльності підприємства, до якого типу галузі воно відноситься: фондомістке, працемістке, енергомістке та iн.

Склад і структура власного капіталу відпові- дно до сучасних нормативно - правових актів, його облік наведено у Національному положенні (стандарті) бухгалтерського обліку 1 «Загальні вимоги до фінансової звітності» [3].

Разом 3 тим власний капітал не є величиною постійною, тому що у часі змінюється його величина, кількість елементів і структура. Виходячи із складу елементів власного капіталу, на його величину і структуру будуть впливати наступні фактори:

- вкладення додаткових внесків за рахунок власників для збільшення статутного капіталу;

- розподіл частини прибутку на накопичення та впровадження інноваційної техніки та технології;

- наскільки своєчасно проводиться дооцінка власного капіталу, враховуючи річний індекс інфляції як основних засобів, так і виробничих запасів (сировини, матеріалів);

- рівень збитковості підприємства, якій впливає на відрахування до резервного та інших фондів, а сама збитковість покривається за рахунок статутного капіталу;

- зменшення статутного капіталу в результаті виходу одного або більше власників за умов, що їх пай не буде викуплений іншими власниками

- знецінення матеріальних благ в результаті відсутності попиту або пошкодження.

Для ефективного формування та використання власного капіталу необхідно розробити механізм управління власним капіталом. Мета управління власним капіталом, на нашу думку - це забезпечення мінімізації витрат на отримання позикового капіталу. На думку В.О.Подольської та О.В. Яріш, оптимізація власного капіталу характеризує «найефективнішу пропорційність між доходністю та фінансовою стійкістю капіталу» [4, с.355]. Разом з тим, в роботі авторів Ю. Брігхема та М. Ерхардта структуру капіталу можна визначити на підставі розрахунків факторів впливу, ризику і практичного досвіду діяльності [5].

Методи регулювання та моделі оптимізації структури капіталу узагальнені в роботі авторів О.Д.Щербань, О.В.Носібової, Н.В. Сухорукова [6], в якій відповідно критеріїв розглядають три моделі:

1. За критерієм максимізації фінансової рентабельності

2. За критерієм мінімізації вартості капіталу

3. За критерієм мінімізації фінансових ризиків.

На нашу думку, кожна модель може бути доповнена іншою частиною моделей, все залежить від того, яку стратегію розвитку вибрано підприємством (умовно-стабільний підхід або консервативний, незначні ризики або помірний підхід, зі значними ризиками або агресивний підхід).

Розглядаючи ефективність використання капіталу з позиції «теорії чистого доходу», Ван Хорн підкреслює, що взаємозв'язок росту чистого доходу і ступеню зростання левериджу, визначає, що структура власного капіталу може впливати на рівень капіталізації і рівень ринкової вартості підприємства [7, c.474-477 ].

Такий підхід буде симулювати впровадження 
інноваційних технологій, які надають можливості значно підвищити КПД використання сировини, матеріалів, праці. Особливе це важливе для підприємств харчової промисловості, яка повинна забезпечувати споживачів якісною, повноцінною, екологічно безпечною продукцією (без антибіотиків, консервантів і стабілізаторів, ГМО, ін'єкцій та ін.)

Також для сучасних підприємств важливим $\epsilon$ рішення соціальних питань розвитку колективу підприємства, тобто забезпечення соціальної відповідаль- ності за працівників. В кінцевому значенні розподіл і використання власного капіталу, як основного джерела розвитку підприємства повинні бути спрямоване на погодження та реалізацію соціально-економічних інтересів всіх суб'єктів підприємства (власників, адміністрацію, робітників та державу)

Розглянемо, яким чином сформована структура власного капіталу та його розміщення впливають на ефективність діяльності м'ясопереробних підприємств України.

Таблиця 1

\section{Динаміка складових власного капіталу та основних показників м'ясопереробних підприсмств}

України, тис. грн.*

\begin{tabular}{|c|c|c|c|c|c|c|c|c|c|}
\hline Підприємство & рік & $\begin{array}{c}\text { Зареєст- } \\
\text { рований } \\
\text { (пайовий) } \\
\text { капітал }\end{array}$ & $\begin{array}{c}\text { Капітал у } \\
\text { дооцін- } \\
\text { ках }\end{array}$ & $\begin{array}{l}\text { Резер- } \\
\text { вний } \\
\text { капітал }\end{array}$ & $\begin{array}{c}\text { Нерозпо- } \\
\text { ділений } \\
\text { прибуток } \\
\text { (непо- } \\
\text { критий } \\
\text { збиток) } \\
\end{array}$ & \begin{tabular}{|c} 
Власний \\
капітал \\
(всього)
\end{tabular} & Баланс & $\begin{array}{c}\text { Необо- } \\
\text { ротні } \\
\text { активи, } \\
\text { всього }\end{array}$ & $\begin{array}{c}\text { Чистий } \\
\text { фінан- } \\
\text { совий } \\
\text { резуль- } \\
\text { тат }\end{array}$ \\
\hline \multirow{3}{*}{$\begin{array}{l}\text { ПрАТ "Богодухов- } \\
\text { ський МК" }\end{array}$} & 2017 & 575 & 2020 & 43 & 3537 & 6175 & 15913 & 9652 & 450 \\
\hline & 2018 & 575 & 2020 & 65 & 4071 & 6731 & 17820 & 10397 & 556 \\
\hline & 2019 & & 2020 & 86 & 5350 & 8031 & & 11717 & 1300 \\
\hline \multirow{3}{*}{$\begin{array}{l}\text { ПрАТ "Меліто- } \\
\text { польський МК" }\end{array}$} & 2017 & 159800 & 0 & 180 & -6105 & 153875 & 354765 & 228644 & -2891 \\
\hline & 2018 & 159800 & 0 & 180 & -6079 & 153901 & 359212 & 227512 & 26 \\
\hline & 2019 & 159800 & 0 & 180 & -6061 & 153919 & 357412 & 225523 & 18 \\
\hline \multirow{3}{*}{$\begin{array}{c}\text { ПрАТ "Українсь- } \\
\text { кий бекон" }\end{array}$} & 2017 & 1001 & 271498 & 0 & -50603 & 221896 & 1281586 & 417689 & 29278 \\
\hline & 2018 & 1001 & 228606 & 0 & -5898 & 223709 & 1176109 & 586937 & 1813 \\
\hline & 2019 & 1001 & 246002 & 0 & -62201 & 184802 & 1681308 & 584602 & -56490 \\
\hline \multirow{3}{*}{$\begin{array}{c}\text { ПрАТ "Козятинсь- } \\
\text { кий МК" }\end{array}$} & 2017 & 113928 & 6262 & 7489 & 57993 & 185672 & 198376 & 96822 & 43193 \\
\hline & 2018 & 113928 & 6262 & 9721 & 100453 & 230364 & 249718 & 103885 & 44692 \\
\hline & 2019 & 113928 & 6262 & 9721 & 145179 & 275090 & 300426 & 124191 & 74673 \\
\hline \multirow{3}{*}{$\begin{array}{c}\text { ПрАТ "Кременчу- } \\
\text { км'ясо" }\end{array}$} & 2017 & 29990 & 0 & 0 & -145090 & -115100 & 532273 & 94586 & -69766 \\
\hline & 2018 & 29990 & 0 & 0 & -251777 & -221787 & 500469 & 92297 & -106181 \\
\hline & 2019 & 29990 & 0 & 0 & -342958 & -312968 & 411093 & 78551 & -91181 \\
\hline
\end{tabular}

* Складено авторами на основі даних фінансової звітності підприємств

За даними табл. 1 можна бачити складові власного капіталу та їх динаміку по кожному з п’яти м'ясопереробних підприємств. На ПрАТ «Український бекон» та ПрАТ «Мелітопольський м'ясокомбінат» загальні суми власного капіталу протягом трьох років, що аналізуються, зменшені на суму непокритого збитку. Через що підприємствами отримано від'ємне значення чистого фінансового результату (збитки): за 2019 рік та 2017 рік відповідно.
На підприємстві ПрАТ «Кременчукм'ясо» загальна сума власного капіталу протягом усього досліджуваного періоду взагалі є від'ємне значення, чистий фінансовий результат також $є$ від'ємним. Тобто можна одразу робити висновки про неефективність ведення господарської діяльності на даному підприємстві.

На інших двох підприємствах можна вважати ведення господарської діяльності та формування власного капіталу задовільним.

Таблиця 2

Показники власного капіталу на м'ясопереробних підприємствах України*

\begin{tabular}{|c|c|c|c|c|c|c|}
\hline Показники & рік & $\begin{array}{c}\text { ПрАТ "Бого- } \\
\text { духовський } \\
\text { МК" }\end{array}$ & $\begin{array}{c}\text { ПрАТ "Меліто- } \\
\text { польський МК" }\end{array}$ & $\begin{array}{c}\text { ПрАТ "Українсь- } \\
\text { кий бекон" }\end{array}$ & $\begin{array}{c}\text { ПрАТ "Козя- } \\
\text { тинський МК" }\end{array}$ & $\begin{array}{c}\text { ПрАТ "Кремен- } \\
\text { чук-м'ясо" }\end{array}$ \\
\hline \multirow{2}{*}{$\begin{array}{c}\text { Коефіцієнт авто- } \\
\begin{array}{c}\text { номії } \\
\text { норма >0,5) }\end{array}\end{array}$} & 2017 & 0,388 & 0,434 & 0,173 & 0,936 & $-0,216$ \\
\cline { 2 - 7 } & 2018 & 0,378 & 0,428 & 0,190 & 0,923 & $-0,443$ \\
\hline
\end{tabular}


Продовження табл.2

\begin{tabular}{|c|c|c|c|c|c|c|}
\hline Показники & рік & $\begin{array}{c}\text { ПрАТ "Бо- } \\
\text { годуховсь- } \\
\text { кий МК" }\end{array}$ & $\begin{array}{c}\text { ПрАТ "Мелі- } \\
\text { топольський } \\
\text { МК" }\end{array}$ & $\begin{array}{c}\text { ПрАТ "Україн- } \\
\text { ський бекон" }\end{array}$ & $\begin{array}{c}\text { ПрАТ "Козя- } \\
\text { тинський } \\
\text { МК" }\end{array}$ & $\begin{array}{c}\text { ПрАТ "Кре- } \\
\text { менчук- } \\
\text { м'ясо" }\end{array}$ \\
\hline $\begin{array}{c}\text { Коефіцієнт фі- } \\
\text { нансової залеж- } \\
\text { ності (норма <2) }\end{array}$ & 2017 & 2,577 & 2,306 & 5,776 & 1,068 & $-4,624$ \\
\cline { 2 - 7 } & 2018 & 2,648 & 2,334 & 5,257 & 1,084 & $-2,257$ \\
\hline $\begin{array}{c}\text { Коефіціснт мане- } \\
\text { вреності власного } \\
\text { капіталу }\end{array}$ & 2019 & 2,559 & 2,322 & 9,098 & 1,092 & $-1,314$ \\
\cline { 2 - 7 } & 2018 & $-0,563$ & $-0,486$ & $-0,882$ & 0,479 & $\mathrm{x}$ \\
\hline \multirow{2}{*}{$\begin{array}{c}\text { Рентабельність } \\
\text { власного капіталу, } \\
\text { \% }\end{array}$} & 2017 & $-0,459$ & $-0,478$ & $-1,624$ & 0,549 & $\mathrm{x}$ \\
\cline { 2 - 7 } & 2018 & 8,29 & $-0,465$ & $-2,163$ & 0,549 & $\mathrm{x}$ \\
\hline \multirow{2}{*yyyyyy}{} & 2019 & 16,49 & 0,02 & 13,19 & 23,26 & $\mathrm{x}$ \\
\hline
\end{tabular}

*Розраховано авторами на основі фінансової звітності даних підприємств

За даними табл.2 можна зробити висновок, що тільки на підприємстві ПрАТ "Козятинський МК" коефіцієнт автономії більше нормативного. На трьох підприємствах коефіцієнти нижче за нормативний, а на ПрАТ «Кременчукм'ясо» через від'ємне значення власного капіталу всі показники мають теж від’ємне значення.

Коефіцієнт фінансової залежності знаходиться в межах норми тільки по підприємству ПрАТ «Козятинський м'ясокомбінат». I тільки по цьому підприємству ми маємо змогу розрахувати коефіцієнт маневреності власного капіталу. На інших підприємствах власний оборотний капітал відсутній - тому коефіцієнти мають від'ємне значення. Рентабельність власного капіталу на достатньому рівні спостерігається тільки по ПрАТ «Козятинський м'ясокомбінат» та ПрАТ «Богодуховський м'ясокомбінат». По інших підприємствах цей показник знаходиться на дуже низькому рівні та навіть у певні періоди має від'ємне значення.

Висновки та перспективи подальших досліджень. В ході проведеного дослідження та аналізу сутності, структури та складу власного капіталу на м'ясопереробних підприємствах для підвищення ефективності їх діяльності нами пропонується наступне:

1. Повинна бути реальна державна програма підтримки підприємств м'ясопереробної галузі, включаючи субвенції та дотації різного роду та можливість отримання дешевих кредитів.

2. При формуванні власного капіталу необхідно враховувати достатній розмір резервного капіталу, який на багатьох підприємствах відсутній через збитковість їхньої діяльності.

3. Своєчасно обов'язково проводити переоцінку та дооцінку власних ресурсів підприємств як джерел додаткового капіталу.

4. До складу додаткового капіталу пропонується включити інноваційний фонд, формування якого буде здійснювати за рахунок частини прибутку, який не буде підлягати оподатковуванню, і має суворе цільове використання на інновацію.

Перспективою подальших досліджень буде визначення оптимальної структури власного капіталу та їі вплив на показники фінансово-економічні діяльності підприємств.

\section{Література}

1. Маркс К. Капитал: в 3 т. Т.2. Критика политической экономии. Т.2. Кн.2 Процесс обращения капитала / под ред. Ф.Энгельса; пер.И.И.Скворцова-Степанова. М.: Политиздат, 1978. 618 с.

2. Щербань О.Д., Струкова М.О. Визначення категорії «власний капітал підприємства» // Економіка i суспільство. №9. 2017. С.736-739

3. Загальні вимоги до фінансової звітності: Національне положення (стандарт) бухгалтерського обліку 1, затв. наказом Міністерства фінансів України від 27.06.2013p. № 628 із змінами від 31.05.2019 p. № 226 URL: https://zakon.rada.gov.ua/laws/show/z1223-13 (дата звернення: 18.12.2020 p.)

4. Подольска В.О., Яріш О.В. Фінансовий менеджмент: навч. посіб. К.: Центр навч. л-ри, 2007. 488c.

5. Бригхем Ю, Эрхард М. Финансовий менеджмент: 10-е изд. / Ю. Бригхем, М. Эрхард; пер. с англ. под ред. к. э. н. Е. А. Дорофеева. СПб.: 2009. 960 с,

6. Щербань О.Д, Носібова Р.В., Сухоруков Р.В. Методи регулювання та оптимізації структури капіталу підприємства // Економіка та держава. №12. 2017. С. 82-88. URL: http://nbuv.gov.ua/UJRN/ecde_2017_12_19. (дата звернення: 04.01.2021 р.)

7. Ван Хорн Дж.К. Основы управления финансами / Ван Хорн Дж.К.; пер. с англ. Гл. ред. серии Я. В. Соколов. М.: Финансы и статистика, 1997. 800 c. URL: https://obuchalka.org/2011061456375/osnovi-upravleniyafinansami-van-horn-dj-k.html (дата зверенння: 09.01.2021 p.)

8. Росс С. Основы корпоративных финансов / Росс С.; пер.с англ. под общ. ред. д.э.н., проф. Ю.В. Шленова. М.: Лаборатория базовых знаний, 2010. 720 с. 
9. Фальченко О.О., Побережна Н.М., Юр'єва І.А. Особливості формування власного капіталу на підприємствах. URL: https://chmnu.edu.ua/wp-content/uploads/2019/07/Falchenko-O.O.-Poberezhna-N.M.-YUr-yevaI.A.pdf (дата звернення: 10.01.2021 p.)

10. Любар О., Болехівська В., Сімаков О. Власний капітал та його вплив на розвиток вітчизняної науки // Економіка та суспільство. 2019. № 20. URL: https://economyandsociety.in.ua/index.php/journal/article/view/19 (дата звернення: 12.01.2021 р.)

11. Погріщук Г. Б., Волощук Р. С. Власний капітал підприємства: сутність і особливості формування в Україні // Економіка та держава. 2020. № 7. С. 16-23. doi: 10.32702/2306-6806.2020.7.16. URL: http://www.economy.in.ua/?op=1\&z=4683\&i=1 (дата звернення: 18.01.2021р.)

12. Kuprina N., Markova T., Volodina O., Stupnytska M. Peculiarities of analysis of enterprise's own capital in modern conditions // Food Industry Economics. 2020. Vol.12, Issue 1. P. 35-44. doi: 10.15673/fie.v12i1.1667

Стаття надійшла 25.01.2021

Стаття прийнята до друку 9.02.2021

Доступно в мережі Internet 18.04.2021

\author{
Oshchepkov 0. \\ Ph.D., Associate Professor \\ Department of Accounting and Auditing \\ E-mail: moto47rod@gmail.com \\ ORCID ID: 0000-0002-7520-1507 \\ Magdenko S. \\ Assistant \\ Department of Industrial Economics \\ Odesa National Academy of Food Technologies \\ Kanatna str., 112, Odesa, Ukraine, 65039 \\ E-mail: maglana1@meta.ua \\ ORCID ID: 0000-0001-6770-6604
}

\title{
ANALYSIS OF EQUITY CAPITAL OF MEAT PROCESSING ENTERPRISES IN UKRAINE AS THE MAIN SOURCE OF THEIR FINANCING AND DEVELOPMENT
}

In the article the questions of formation, distribution and use of equity capital, as a basic source of financing and development of enterprises have been considered. The registered or share capital makes basis of equity capital, according to the charter of enterprise. The problem is to effectively distribute it between separate elements, that is between the fixed and circulating assets, by material and non-material assets with the purpose of achievement of maximal effect from its use.

The different approaches to the concept "Equity capital" have been considered, and also its functions have been determined, that must provide stability of functioning and development of enterprise, decrease economic risks in the conditions of instability of the country development.

The size of equity capital is not permanent. During realization of economic activity equity capital can both increase in dynamics and diminish, as well as change its structure. The factors of influence that are divided into internal and external have been given. Also in the research of equity capital structure it is necessary to note that the existing structure can influence the level of capitalization and cost of enterprise.

The analysis of formation, distribution and use of equity capital, has been conducted on the enterprises of meat processing industry of Ukraine, efficiency of use of equity capital has been calculated.

The research results allow to make the following conclusions, that on the most of enterprises additional funds, as elements of equity capital, are absent taking into account considerable unprofitableness of activity of enterprises, that, in turn, considerably diminishes the share of equity capital in all capital structure and results in the increase of part of loan capital. All the above-mentioned results in the enterprises' becoming noncompetitive in the market.

Insufficiency of own resources and high cost of external resources do not allow the enterprises to introduce the newest facilities and technologies, to change over to the innovative forms of development. Also absence of state support, the high tax load induce to use the charts of double entry bookkeeping, and the shadow market.

Key words: capital, equity capital, analysis, structure, optimality (efficiency). 


\section{References}

1. Marks, K. (1978). Kapital. (I. I. Skvortsov-Stepanov, Trans., F. Engels, Ed.) (Vol. 2). Politizdat.

2. Shcherban, O. D., \& Strukova, M. O. (2017). Vyznachennia katehorii «vlasnyi kapital pidpryiemstva». Ekonomika i Suspilstvo, (9), 736-739.

3. Zahalni vymohy do finansovoi zvitnosti: Natsionalne polozhennia (standart) bukhhalterskoho obliku 1, zatv. nakazom Ministerstva finansiv Ukrainy vid 27.06.2013r. № 628 iz zminamy vid 31.05.2019 r. № 226. (2019). Retrieved December 18, 2020, from https://zakon.rada.gov.ua/laws/show/z1223-13.

4. Podolska, V. O., \& Yarish, O. V. (2007). Finansovyi menedzhment. Tsentr navch. 1-ry.

5. Brighem, Yu., \& Erhard, M. (2009). Finansoviy menedzhment. (E. A. Dorofeev, Trans.) (10th ed.).

6. Shcherban, O. D., Nosibova, R. V., \& Sukhorukov, R. V. (2017). Metody rehuliuvannia ta optymizatsii struktury kapitalu pidpryiemstva. Ekonomika Ta Derzhava, (12), 82-88. Retrieved January 04, 2021, from http://nbuv.gov.ua/UJRN/ecde_2017_12_19.

7. Van Horn, Dzh. K. (1997). Osnovyi upravleniya finansami. (Ya. V. Sokolov, Trans.). Finansyi i statistika. Retrieved January 09, 2021, from https://obuchalka.org/2011061456375/osnovi-upravleniya-finansami-van-horn-djk.html.

8. Ross, S. (2010). Osnovyi korporativnyih finansov (Yu.V. Shlenova, Trans.). Laboratoriya bazovyih znaniy.

9. Falchenko, O. O., Poberezhna, N. M., \& Yur'ieva, I.A. Osoblyvosti formuvannia vlasnoho kapitalu na pidpryiemstvakh. Retrieved January 10, 2021, from https://chmnu.edu.ua/wp-content/uploads/2019/07/Falchenko-O.O.Poberezhna-N.M.-YUr-yeva-I.A..pdf

10. Liubar, O., Bolekhivska, V., \& Simakov, O. (2019). Vlasnyi kapital ta yoho vplyv na rozvytok vitchyznianoi nauky. Ekonomika ta suspilstvo, (20). Retrieved January 12, 2021, from https://economyandsociety.in.ua/index.php/journal/article/view/19

11. Pohrishchuk, H. B., \& Voloshchuk, R. Ye. (2020). Vlasnyi kapital pidpryiemstva: sutnist i osoblyvosti formuvannia v Ukraini. Ekonomika ta derzhava, (7), 16-23. doi: 10.32702/2306-6806.2020.7.16 Retrieved January 18, 2021, from http://www.economy.in.ua/?op=1\&z=4683\&i=1

12. Kuprina, N., Markova, T., Volodina, O., \& Stupnytska, M. (2020). Peculiarities of analysis of enterprise's own capital in modern conditions. Food Industry Economics, 12(1), 35-44. doi: 10.15673/fie.v12i1.1667

Received 25 January 2021

Approved 9 February 2021

Available in Internet 18.04.2021

Цитування згідно ДСТУ 8302:2015

Ощепков О.П., Магденко С.О. Аналіз власного капіталу м'ясопереробних підприємств України як основного джерела їхнього фінансування та розвитку // Економіка харчової промисловості. 2021. Т.13, вип. 1. С.43-48.

Cite as APA style citation

Oshchepkov, O., \& Magdenko, S. (2021). Analysis of equity capital of meat processing enterprises in Ukraine as the main source of their financing and development. Food Industry Economics, 13(1), 43-48. 